\title{
Analysis of Antibiotic Resistance in Escherichia Coli Strains, Isolated from Urine Cultures in Laboratories of Kashmar, Iran
}

\author{
M Zare' ${ }^{1}$ MR Bayhaqi², R Zare ${ }^{3}$
}

\begin{abstract}
Background and Aims: Resistance of bacteria, causing urinary tract infections, is increasing with indiscriminate prescription of antibiotics. Such resistance has even emerged in stronger antibiotics. This study was performed to evaluate the antibiotic resistance pattern in Escherichia coli (E coli) isolated in laboratories of Kashmar, with particular attention to nalidixic acid (NA) and co-trimoxazole (SXT).

Materials and Methods: A total of 50 samples of positive E coli strains were collected in Kashmar laboratories and confirmed by the standard biochemical method (Gallery). Evaluation of antibiotic susceptibility and resistance was performed by Mueller-Hinton agar for disk diffusion.

Results: Out of 50 samples, resistance to co-trimoxazole and nalidixic disks was higher, considering the curves.

Conclusion: The obtained curves related to the studied antibiotics show that in this region, due to indiscriminate use of antibiotics and lack of restrictions in using antibiotics, resistance of some bacteria has increased.
\end{abstract}

Keywords: Antibiotic resistance, Escherichia Coli, urinary tract infection

\section{Análisis de resistencia a los Antibióticos en las Cepas de Escherichia Coli, Aisladas de Cultivos de Orina en los Laboratorios de Kashmar, Irán}

\author{
M Zare ${ }^{1}$, MR Bayhaqi ${ }^{2}$, R Zare $^{3}$
}

\begin{abstract}
RESUMEN
Antecedentes y objetivos: La resistencia de las bacterias que causan infecciones del tracto urinario, está aumentando debido a la prescripción indiscriminada de antibióticos. Esa resistencia ha surgido incluso con los antibióticos más fuertes. Este estudio fue realizado para evaluar el patrón de resistencia a antibióticos en Escherichia coli (E coli) aisladas en los laboratorios de Kashmar, con especial atención al ácido nalidíxico (NA) y al cotrimoxazol (SXT).

Materiales y métodos: Un total de 50 muestras de cepas de E coli positivo fueron recogidas en los laboratorios de Kashmar y confirmadas por el método bioquímico estándar (Gallery). La evaluación de la susceptibilidad y resistencia a los antibióticos fue realizada mediante la difusión de disco Agar MuellerHinton.

Resultados: De las 50 muestras, la resistencia al cotrimoxazol y a los discos nalidíxicos fue mayor, considerando las curvas.

Conclusión: Las curvas obtenidas en relación con los antibióticos estudiados muestran que en esta región, debido al uso indiscriminado de antibióticos y la falta de restricciones en el uso de antibióticos, ha aumentado la resistencia de algunas bacterias.
\end{abstract}

From: ${ }^{1}$ Golestan University of Medical Sciences, Gorgan, Iran, ${ }^{2}$ Nursing Department, Mashhad University of Medical Sciences, Iran and ${ }^{3}$ Nursing Department, Infectious Disease Specialist, Golestan University of Medical Sciences, Iran.
Correspondence: Dr MR Bayhaqi, LaboratoryE xpert, Kashmar, Iran. Fax: +9838414499, e-mail: telehealth.ir@gmail.com. 
Palabras claves: Resistencia a los antibióticos, Escherichia Coli, infección del tracto urinario

\section{INTRODUCTION}

Clinically, urinary tract infection presents with a range of symptoms including dysuria, frequent urination, fever, flank pain and pain in the upper part of the pelvis (1); this condition is diagnosed based on the presence of infectious agents and laboratory confirmation [by urine cultures] (2-3).

From the experimental standpoint, urinary infection is confirmed by the separation of at least one pure bacteria (in some cases, two or more) from urine samples, cultured by standard methods, with colony count of more than 20000 ; biochemical tests were performed for confirmation of bacteria strains and in some cases, serotype was required (4).

Treatment of urinary tract infection varies with regard to age, gender, underlying diseases and whether the infection is found in the upper or lower urinary tract (5). Considering the spread of infectious diseases in every country, antibiotics used to treat $E$ coli urinary tract infections include nitrofurantoin, cephalothin, nalidixic acid, co-trimoxazole, ciprofloxacin, gentamicin, norfloxacin and the cephalosporins (6).

Recently, according to several studies, with the increase of antibiotic resistance in $E$ coli, treatment of urinary tract infections has been quite challenging (7). Since $E$ coli was the predominant pathogenic agent, this study was performed to evaluate the antibiotic resistance pattern in laboratories of Kashmar, Iran.

\section{SUBJECTS AND METHODS}

Fifty samples of $E$ coli were isolated from urine cultures of patients with urinary tract infection. Their demographic characteristics are listed in the Table.

Table: Age and gender distribution

\begin{tabular}{lccc}
\hline Gender & Number of patients & Age $(\mathbf{1}-\mathbf{1 8}$ years) & Age (18-50 years) \\
\hline Male & $13(26 \%)$ & $3(17 \%)$ & $10(73 \%)$ \\
Female & $37(74 \%)$ & $7(22 \%)$ & $30(78 \%)$ \\
\hline
\end{tabular}

Samples were collected from all city laboratories and all E coli samples were separated and confirmed by biochemical tests including methyl red, Voges-Proskauer (MRVP), triple sugar iron (TSI), simmon citrate and sulfur indole motility media (SIM). The difference in resistance to different antibiotics was evaluated.

\section{Bacterial resistance and susceptibility tests}

Susceptibility and bacterial resistance patterns were evaluated by placing the antibiotics on Mueller-Hinton agar medium one by using disk diffusion method and [0.5 McFarland] (8).

Disks of ciprofloxacin $(5 \mu \mathrm{g})$, gentamicin $(10 \mu \mathrm{g})$, nalidixic acid $(30 \mu \mathrm{g})$, cephalothin $(30 \mu \mathrm{g})$, nitrofurantoin $(300$ $\mu \mathrm{g})$, norfloxacin $(10 \mu \mathrm{g})$ and trimethoprim/sulfamethoxazole $(23.75 / 1.25 \mu \mathrm{g})$, made by Padtan-Teb Co. Two were used for antibiogram evaluation (Fig. 1).

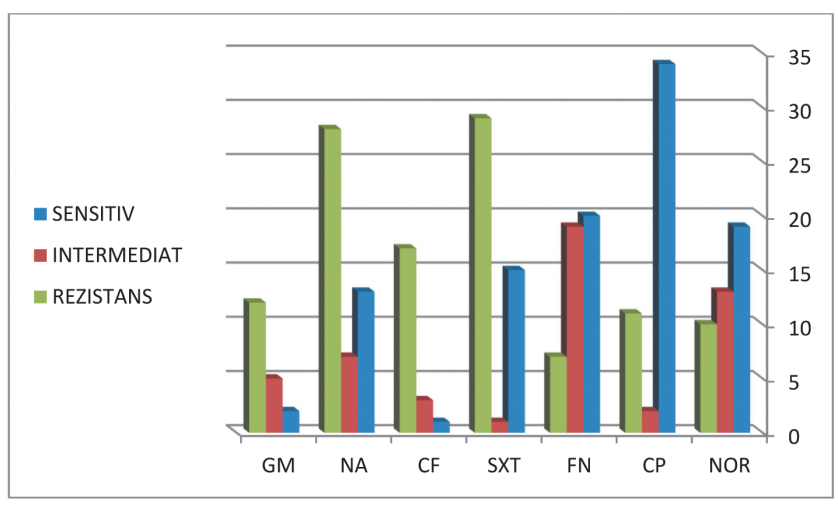

Fig. 1: Diagram of antibiogram in $E$ coli infection.

\section{RESULTS}

In this study, resistance to co-trimoxazole (SXT) and nalidixic acid (NA) was higher than resistance to other agents (Fig. 2). According to the chart, rate of urinary tract infection was lower in men, compared to women, and higher in the age group of $18-50$ years.

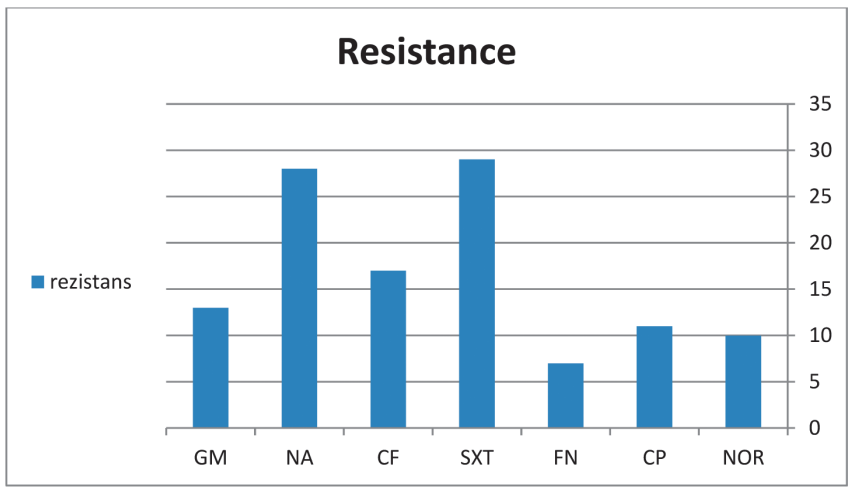

Fig. 2: Diagram of antibiotic resistance in $E$ coli urinary tract infections.

\section{DISCUSSION AND CONCLUSION}

Over-time, antibiotic treatment has become a challenging issue for public health authorities with the emerging resistance to antibiotics due to indiscriminate use of these agents. To resolve this problem, the following measures can be taken: 1) indiscriminate use of antibiotics should be limited; 2) restriction rules should be legislated; 3) antibiotics without performing antibiogram should not be administered; and 4) treatment recommendations, particularly for full consumption of antibio-tics, should be provided (9). 


\section{REFERENCES}

1. Gatermann SG. Bacterial infections of the urinary tract. In: Borriello P, Murray PR, Funke G, editors. Topley Wilson's microbiology and microbial infections. 10th ed. London: Hodder Arnold Publishers; 2007. pp. 671-83.

2. Karlowsky JA, Jones ME, Thornsberry C, Critchley I, Kelly LJ, Sahm DF. Prevalence of anti-microbial resistance among urinary tract pathogens isolated from female outpatients across the US in 1999. Int J Antimicrob Agents 2001; 18:121-7.

3. Gorbach SL, Bartlett JG, Balcklow NR. Urinary tract. In: Gorbach SL, Bartlett JG, Balcklow NR, editors. Infectious diseases. Philadelphia: Lippincott Williams \& Wilkins Publisher; 2004. pp. 861-81.

4. Warren JV, Abrutyn E, Hebel R, Johnson JR, Schaeffer AJ, Stamm WE. Guidelines for the treatment of uncomplicated acute bacterial cystitis and acute pyelonephritis in women. Clin Infect Dis 1999; 29: 745-58.
5. Karlowsky JA, Kelly LJ, Thornsberry C, Jones ME, Sahm DF. Trends in antimicrobial resistance among urinary tract infection isolates of Escherichia coli from female outpatients in the United States. Antimicrob Agents Chemother 2002; 46: 2540-5.

6. Kahlmeter G. An international survey of the antimicrobial susceptibility of pathogens from uncomplicated urinary tract infections: the ECO-SENS Project. J Antimicrob Chemother 2003; 51: 69-76.

7. Kauser Y, Chunchanur SK, Nadagir SD, Halesh LH, Chandrashekhar MR. Virulence factors, serotypes and antimicrobial susceptibility patterns of Escherichia coli in urinary tract infections. AJMS 2009; 2: 47-51.

8. Tabibian JH, Gornbein J, Heidari A, Dien SL, Lau VH, Chahal P et al. Uropathogens and host characteristics. J Clin Microbiol 2008; 46: 39806.

9. Performance of standards for antimicrobial disk susceptibility tests; approved standards.10th ed. Vol. 29. Wayne, PA: CLSI; 2009. Clinical Laboratories Standards Institute (CLSI) M02-A10. 